\title{
Effects of feeding system and pre-partum supplementation on the $\beta$-carotene status of South African Holstein cows
}

\author{
L.J. Erasmus ${ }^{1 \#}$, G. Machpesh ${ }^{1}$, R.J. Coertze ${ }^{1} \&$ C.J.L. du Toit ${ }^{1}$ \\ ${ }^{1}$ Department of Animal Science, University of Pretoria, Private Bag X20, Hatfield 0028, South Africa
}

(Received 4 July 2020; Accepted 9 March 2021; Published 19 May 2021)

\begin{abstract}
Copyright resides with the authors in terms of the Creative Commons Attribution 4.0 South African Licence.
See: http://creativecommons.org/licenses/by/4.0/za

Condition of use: The user may copy, distribute, transmit and adapt the work, but must recognise the authors and the South African Journal of Animal Science.
\end{abstract}

\begin{abstract}
The objectives were to investigate the $\beta$-carotene status of dairy cows under various production systems, and to determine the effect of pre-partum $\beta$-carotene supplementation on their post-partum $\beta$ carotene status. Ten farms were selected from each of the three production systems, namely pasture-based, hay-based total mixed ration (TMR) and silage-based TMR. Twenty cows per farm were sampled in each system, and blood plasma $\beta$-carotene concentration was determined with a portable spectrophotometer $(n=$ 200 cows per system). Mean blood $\beta$-carotene concentrations of pasture-fed cows were $5.54 \mathrm{mg} / \mathrm{L}$, and were higher $(P<0.05)$ than concentrations of cows on hay-based $(2.98 \mathrm{mg} / \mathrm{L})$ and maize silage-based TMR systems $(1.71 \mathrm{mg} / \mathrm{L})$; in $\beta$-carotene status, therefore, these systems were optimal, marginal, and deficient, respectively. In the second experiment, 10 cows received a hay-based control TMR, and 10 were supplemented with $1.2 \mathrm{~g} /$ day of $\beta$-carotene pre-partum from day -56 to calving and monitored until day 56 postpartum. The supplemented cows were in optimal $\beta$-carotene status until calving, with a minor carry-over effect until 10 days post partum, and then declined gradually in status until they needed supplementation. The $\beta$-carotene status between the groups differed from three weeks pre-partum to two weeks post partum, with the control group being marginal to deficient from three weeks pre-partum onwards. Forage type and its $\beta$-carotene content play a major role in the $\beta$-carotene status of cows and more research is needed on the potential storage and mobilization of $\beta$-carotene in cows.
\end{abstract}

Keywords: $\beta$-carotene content, $\beta$-carotene storage, dairy production systems, forage

${ }^{\#}$ Corresponding author: lourens.erasmus@up.ac.za

\section{Introduction}

Continuous selection for high milk production has led to reduced reproductive performance and fertility, especially in Holstein herds. This situation has resulted in reduced profitability in high-producing herds (Butler, 2000; Berry et al., 2014). In many instances the cause of low fertility is considered nutritional, at least in part, and could therefore be corrected through nutritional intervention and dietary adjustment (Roche et al., 2011). Many nutritionists regard a negative energy balance and the resulting oxidative stress early in lactation as the main cause of fertility problems owing to suboptimal antioxidant uptake through the diet (De Bie, 2019). Fresh grass is the most important source of dietary vitamins and antioxidants such as $\beta$ carotene, which is the major natural precursor of vitamin $A$ in cattle and of vitamin $E$, and contributes significantly to their health, fertility, and antioxidative status (Ballet et al., 2000). In many countries there are limitations to the grazing capacity for dairy cows and high-producing dairy herds follow zero grazing systems, in which the major fibre sources are ensiled forage and hay, which are low in vitamins and antioxidants and may increase the incidence of vitamin and antioxidant deficiencies (Wilkinson \& Rinne, 2018).

Deficiencies in vitamins can be corrected only if there are proper guidelines. Dietary $\beta$-carotene has an activity of $400 \mathrm{IU} / \mathrm{mg}$. NRC (2001) recommends $110 \mathrm{IU}$ vitamin A per kg of bodyweight for mature dairy cows, but makes no recommendations for $\beta$-carotene because there were insufficient research data to establish a requirement, although a number of studies reported the benefits of supplementing $\beta$-carotene (de Ondarza et al., 2009; Kumar et al., 2010). Low levels of circulating $\beta$-carotene have been associated with low progesterone concentrations and conception rates, prolonged oestrus, delayed ovulation and lowering in the intensity of signs of oestrus (Hemken \& Bremel, 1982; Rakes et al., 1985; Arikan \& Rodway, 2000). Lothammer $(1978 ; 1979)$ reported that supplemental $\beta$-carotene improved uterine involution, conception 
rates, and ovulation, and reduced the incidence of cystic ovaries and early embryonic death. De Ondarza et al. (2009) observed increases in milk fat yield and 3.5\% fat-corrected milk in early lactation, improvements in 21 -day pregnancy rates, and a reduction in early embryonic mortality. Oliveira et al. (2015) found that $\beta$ carotene supplementation was associated with a lower incidence of retained placenta in multiparous cows. Other researchers, however, did not observe positive reproductive responses to $\beta$-carotene supplementation, possibly owing to the influence of season and $\beta$-carotene status of animals (Akorder et al.,1986; Weis, 1998).

Information on the $\beta$-carotene status of dairy cows is scarce. Block and Farmer (1987) and De Bie et al. (2019) conducted studies to determine the $\beta$-carotene status of dairy herds in Quebec and Flanders and found what considerable variation in $\beta$-carotene status. Similar to these studies, there was a dearth of information on the $\beta$-carotene status of dairy cows in South Africa. Factors such as diet and plant species, maturity, leaf to stem ratio, sunlight exposure, storage, ensilage, and wilting and cutting of forages can all play a role in the $\beta$-carotene content of forages.

There is also conflicting evidence about the impact of $\beta$-carotene supplementation of dairy cows during the dry and transition periods on post-partum $\beta$-carotene status, that is, the potential carry-over effect. Kaewlamun et al. (2011) found that eight weeks of pre-partum supplementation increased plasma $\beta$ carotene for only two weeks post partum. Bian et al. (2007) reported no effect of pre-partum supplementation of $300 \mathrm{mg} / \mathrm{day} \beta$-carotene in one study, but in a second study they found differences compared with the control up to 60 days post partum. The aims of the current study were first to investigate the $\beta$-carotene status of lactating Holstein cows exposed to the three most common feeding systems in South Africa and second to assess the potential carry-over effect of pre-partum $\beta$-carotene supplementation on post-partum blood plasma levels of $\beta$-carotene.

\section{Materials and Methods}

Ethical approval was granted by the Research Committee of the Department of Animal and Wildlife Sciences, Faculty of Natural and Agricultural Sciences, University of Pretoria (Project GM-13).

The three major dairy feeding regimes in South Africa are pasture-based (kikuyu/ryegrass) with mineral-based concentrate supplementation (system 1), predominantly lucerne (Medicago sativa) hay-based TMR (system 2), and predominantly maize silage-based TMR (system 3). A total number of 30 farms were identified, with 10 farms for each regime. The pasture-based systems included five farms from KwaZuluNatal (KZN) and five from Eastern Cape (EC). The twenty TMR-based farms were predominantly from Gauteng, Mpumalanga, and the Free State. The farms were selected to be as representative as possible in coverage for a specific province and of the willingness of farmers and their veterinarians to assist with sampling. Twenty healthy multiparous cows were randomly selected for blood sampling from each of the 10 herds in a feeding system. Cows were more than 60 days in milk (DIM). This was required because $\beta$ carotene analyses of blood plasma of cows fewer than 60 DIM show more variability (Schweigert, 2010, personal communication, Institute of Physiology, Ludwig-Maximilians University, Munich, Germany). Whole blood samples were taken from the coccygeal vein after the first morning milking, and analysed for $\beta$ carotene content with a hand-held portable spectrophotometer (Schweigert \& Immig, 2007) through the iCheck $^{\mathrm{TM}}$ procedure (BioAnalyt $\mathrm{GmbH}$, Germany). This procedure was performed on farm for real-time $\beta$ carotene assessment.

The forage samples were analysed for $\beta$-carotene, according to this procedure. Approximately $10 \mathrm{ml}$ blood was drawn from each cow using the vacutainer system, with each tube containing $\mathrm{NH}$ (sodium heparin). A sample of $0.4 \mathrm{ml}$ blood was drawn from each vacutainer with a $1 \mathrm{ml}$ syringe and injected into an extraction ampule. Each ampule was then shaken intensively for 10 seconds and then left for 5 minutes to allow the $\beta$-carotene pigment to separate from the blood into the organic fluid in the ampules. The extraction vial was then placed in the iCheck hand-held photometer for B-carotene analyses. The photometer was kept out of direct sunlight and placed on a flat level surface. On the day of blood sampling, representative samples of the forage were taken, placed on ice and frozen until analysis. Sampling of the forage and blood plasma for pasture farms in KZN and EC was done in October, which is the summer and high rainfall season for both areas. All the farms are on irrigated grass pasture year round (predominantly rye). It could therefore be assumed that fluctuations in $\beta$-carotene plasma concentration would not be significant. However, some farmers supplement with silage during the dry months and this could reduce the $\beta$-carotene content of the feed. The hay-based systems were sampled in summer (September-November) and the maize silage-based systems were sampled in winter (June-July).

The second trial was conducted at the University of Pretoria Experimental Farm in Hatfield. Twenty randomly selected Holstein cows, stratified by current weight and milk production during previous lactations, were allocated to control and treatment groups of 10 cows each. Cows were kept in single pens to monitor 
daily feed intake and fresh clean water was available ad libitum. The duration of the trial was from 60 days pre-partum until 56 days post partum.

The control group was fed $8 \mathrm{~kg}$ dry matter (DM) of a lucerne/maize-based TMR. The treated group received the same diet supplemented with $12 \mathrm{~g} /$ day $10 \%$ Rovimix ${ }^{\circledR} \beta$-carotene (DSM Nutritional Products Ltd., Basel, Switzerland) providing $1.2 \mathrm{~g} /$ day of $\beta$-carotene from 60 days pre-partum until calving. The $\beta$ carotene supplement was mixed with a carrier (corn starch-coated matrix of porcine gelatine and carbohydrates) and hand mixed into the $8 \mathrm{~kg}$ TMR daily. The control group received only the carrier. The TMR was palatable because of the high-quality lucerne hay and generally there were no refusals. In addition to the TMR, cows had ad libitum access to Eragrostis curvula hay. After calving, the experimental and control groups of animals received the same TMR ad libitum, without supplementation. The ingredients and chemical composition of the TMR are shown in Table 1.

Table 1 Ingredient and chemical composition of the total mixed ration fed to Holstein dairy cows without further supplementation or with supplementation with $1.2 \mathrm{~g} /$ day of $\beta$-carotene

\begin{tabular}{lrlc}
\hline Ingredients & \% Dry matter (DM) & Chemical composition & Amount \\
\hline Yellow maize & 21.30 & Crude protein (CP), \% DM & 16.6 \\
Hominy chop & 5.02 & Undegradable dietary protein, \% CP & 42.6 \\
Defatted maize germ & 11.10 & Metabolizable energy, MJ/kg DM & 11.5 \\
Full fat soya & 6.63 & Neutral detergent fibre, \% DM & 32.1 \\
Soya oil cake & 2.22 & Total fat, \% DM & 6.28 \\
Fishmeal & 2.50 & Calcium, \% DM & 0.94 \\
Molasses meal & 5.76 & Phosphorus, \% DM & 0.43 \\
Soya oil & 0.61 & Magnesium, \% DM & 0.37 \\
Limestone & 0.81 & Potassium, \% DM & 1.45 \\
Salt & 0.23 & Sulphur, \% DM & 0.20 \\
Magnesium sulphate & 0.12 & & \\
Magnesium oxide & 0.41 & & \\
Urea & 0.17 & & \\
Vit/Min premix & 0.30 & & \\
Sodium bicarbonate & 0.40 & & \\
Rumen protected fat & 1.44 & & \\
Lucerne & 26.60 & & \\
Eragrostis hay & 14.40 & &
\end{tabular}

\footnotetext{
${ }^{1}$ Megalac $\AA$

${ }^{2}$ Vitamin/mineral premix (organic) (DSM Nutritional Products (Pty) Ltd., South Africa): $7.23 \%$ manganese, $7.50 \%$ zinc, $1.83 \%$ copper, $0.11 \%$ cobalt, $0.14 \% \mathrm{l}, 0.03 \%$ selenium( $1 \%), 1.28 \%$ organic manganese, $2 \%$ organic zinc, $0.32 \%$ organic copper, $0.01 \%$ organic selenium, 5\% Rumensin (20\%), 3.5\% Stafac, 96250 IU vitamin A, 28875 IU vitamin $D_{3}, 577.5$ $\mathrm{mg}$ vitamin $\mathrm{E} /$ cow/d
}

Samples of the TMR and Eragrostis curvula hay were taken weekly and pooled on an eight-weekly basis. Samples were analysed for DM, ash, CP, acid detergent fibre (ADF), neutral detergent fibre (NDF), acid detergent lignin (ADL), gross energy (GE), in vitro organic matter digestibility (IVOMD), fat, calcium $(\mathrm{Ca})$, and phosphorus $(\mathrm{P})$ at the Analytical Laboratory of the Department of Animal and Wildlife Science at the University of Pretoria in South Africa. All samples were ground through a 1-mm sieve using a Retsch ZM 200 (Germany) grinder. Dry matter content was determined as the loss in mass of the sample after drying at $95-100{ }^{\circ} \mathrm{C}$ (method 934.01). Ash was reported as a percentile by using a temperature-controlled furnace at $600{ }^{\circ} \mathrm{C}$ for two hours (method 942.05) and CP was determined (method 968.06) (AOAC, 2000). Acid detergent fibre and NDF were analysed with an Ankom 2000 automated fibre analyser (Ankom Technology, NY, USA) according to the instructions supplied by the manufacturer. Acid detergent lignin was determined by applying the ADF method to the sample and saturating in $72 \%$ sulphuric acid $\left(\mathrm{H}_{2} \mathrm{SO}_{4}\right)$ for three hours, 
stirring every 30 minutes. Acid was then removed by suction and the sample was washed three times with hot water (Goering \& Van Soest, 1970). Gross energy was measured using a bomb calorimeter (MC-1000 modular calorimeter, Energy Instrumentation, 135 Knoppieslaagte, Centurion, South Africa). The Tilley and Terry method (1963) as modified by Engels and Van der Merwe (1967) was used to estimate in vitro organic matter digestibility. Metabolizable energy was predicted with the equation ME $(\mathrm{MJ} / \mathrm{kg} \mathrm{DM})=0.82 \times(\mathrm{GE} \times$ IVOMD) (Robinson et al., 2004). The fat content of the diet was determined by ether extraction using the Soxtec System HT 1043 extraction Unit (Foss Analytical, Hillerød, Denmark) (method 920.39) (AOAC, 2000). Calcium content of feed was measured by the method of Giron (1973). The P content was determined by ashing the sample, adding hydrochloric acid $(\mathrm{HCL})$ and nitric acid $\left(\mathrm{HNO}_{3}\right)$ and boiling, using molybdovanadate reagent and a spectrophotometer at $400 \mathrm{~nm}$ (method 965.17) and sample preparation by method 968.08 (AOAC, 2000). The $\beta$-carotene content of the feed was measured by direct saponification in ethanolic solution and pigment extraction into hexane by EXtrelut columns and then analysed with high performance liquid chromatography (HPLC) (Schierle et al., 1995) Blood samples were taken weekly from the coccygeal vein commencing at the beginning of the dry period (60 days pre-partum) until 56 days post partum. Samples were analysed for plasma $\beta$-carotene as described in experiment 1.

Data from the first experiment were analysed with one-way analysis of variance using the GLM procedure (SAS Institute, Inc., Cary, North Carolina, USA) to determine the average effects of systems. Means and standard errors were calculated and significance of differences $(P<0.05)$ between means were assessed using Fischer's test (Samuels, 1989). Data from the second experiment were analysed as a randomized block design with the SAS GLM procedure. Means and standard errors were calculated and significance of differences $(P<0.05)$ between means were assessed with Fischer's test (Samuels, 1989). The linear model was as follows:

$$
Y_{i j k}=\mu+B_{i}+T_{j}+e_{i j k}
$$

Where: $Y_{i j k}=$ a measure of an independent variable from the kth cow,

$\mu=$ the overall mean,

$B_{i}=$ the effect of the ith block,

$T_{j}=$ the effect of the jth treatment, and

$e_{i j k}=$ random error.

\section{Results and Discussion}

The $\beta$-carotene content ( $\mathrm{mg} / \mathrm{kg} \mathrm{DM}$ ) of the forage used in these feeding systems are shown in Table 2. Although ryegrass was the predominant roughage source in system 1 , two of the samples contained approximately $20 \%$ lucerne and $20 \%$ clover pasture, respectively. Among the hay samples, one sample was a 50:50 mixture of lucerne and Eragrostis curvula hay. The values and ranges of $\beta$-carotene content of the forages in the current study agree with data published by McDowell (2000) and Ballet et al. (2000). The considerable variations in $\beta$-carotene content suggest that a number of factors contributed to this variability. Park et al. (1983) reported that the $\beta$-carotene content of lucerne hay cut at the flowering stage was reduced from $53 \mathrm{mg} / \mathrm{kg}$ DM to $21.8 \mathrm{mg} / \mathrm{kg} \mathrm{DM}$ by increasing the time of sun drying from 48 hours to 96 hours. Livingston (1970) found $\beta$-carotene losses of $42 \%$ to $72 \%$ after 12 weeks of storage at $32{ }^{\circ} \mathrm{C}$. Ballet et al. (2000) reviewed the impact of origin, climatic conditions, stage of maturity, conservation and storage conditions on the $\beta$-carotene content of forages in detail. Plants with a higher concentration of leaves to stem generally contained higher levels of $\beta$-carotene. At advanced stages of growth, legumes are better sources of $\beta$-carotene compared with grasses, because of the higher proportion of leaves in legumes, supporting the current results. At the flowering stage, however, grasses and legumes have approximately the same levels of $\alpha$-tocopherol and $\beta$-carotene (Marino et al., 2014). In general, the $\beta$-carotene content of silages is significantly lower than those of grasses and legumes such as lucerne (McDowell, 2000; Mogensen, 2012; Machpesh, 2014) as found in the current study. Block and Farmer (1987), who investigated the $\beta$-carotene status of cows from 100 Quebec dairy herds, reported a mean $\beta$-carotene concentration in silage of only 1.6 $\mathrm{mg} / \mathrm{kg} \mathrm{DM}$.

The reliability of blood plasma $\beta$-carotene concentration as an accessible indicator of the $\beta$-carotene status of dairy cows was confirmed by Ralston and Dyer (1959) and Kirchgessner et al. (1967). These authors found that the body pool and storage of $\beta$-carotene was largest in blood plasma and not in the corpus luteum (CL), adipose tissue or liver. For this reason, Schweigert and Immig (2007) developed the cow side (iCheck) test using a portable spectrophotometer with the ability to analyse whole blood samples from the tail vein within 5 minutes. The test was validated under experimentally controlled conditions and a high correlation $\left(R^{2}=0.94-0.99\right)$ was found between iCheck and HPLC methods (Schweigert \& Immig, 2007; Islam \& Scheigert, 2015). More recently, De Bie et al. (2019) validated the iCheck against HPLC analyses and found high correlations under variable field conditions. 
Table $2 \beta$-carotene content of forages (mg/kg DM) fed to cows on a pasture-based system (system 1), haybased total mixed ration (system 2) and a maize silage-based total mixed ration (system 3) milk production system

\begin{tabular}{lcccc}
\hline System & N & Mean & Minimum & Maximum \\
\hline 1 Ryegrass pasture & 6 & $20.9 \pm 3.3^{\mathrm{a}}$ & 14.3 & 31.5 \\
2 Lucerne hay & 5 & $26.5 \pm 3.6^{\mathrm{a}}$ & 12.8 & 38.6 \\
3 Maize silage & 6 & $3.70 \pm 3.3^{\mathrm{b}}$ & 0.3 & 6.3 \\
\hline a,b & & &
\end{tabular}

${ }^{a, b}$ Means with a common superscript did not differ with probability $P=0.05$

The mean plasma $\beta$-carotene concentration of cows under the three feeding systems in the current study is shown in Table 3. For interpretation purposes the most recent reference values on the optimal plasma $\beta$-carotene concentrations are the recommendations published by Schweigert and Immig (2007). Blood concentrations less than $1.5 \mathrm{mg} / \mathrm{L}$ indicate a deficient status, and supplementation of at least $500 \mathrm{mg}$ $\beta$-carotene/cow/day is recommended. Blood concentrations of $\beta$-carotene from 1.5 to $3.5 \mathrm{mg} / \mathrm{L}$ require supplementation of a minimum of $300 \mathrm{mg} \beta$-carotene/cow/day. When blood concentrations are greater than $3.5 \mathrm{mg} / \mathrm{L}$ the cow has optimal $\beta$-carotene status.

Table 3 Mean plasma $\beta$-carotene concentration of cows on a pasture-based diet, hay-based total mixed ration, and a maize silage-based total mixed ration diet, 200 cows per treatment

\begin{tabular}{lcccc}
\hline System & Mean $(\mathrm{mg} / \mathrm{L})$ & Minimum & Maximum & Status $^{1}$ \\
\hline 1 Ryegrass pasture & $5.54 \pm 0.47^{\mathrm{a}}$ & 1.92 & 11.16 & $\mathrm{O}$ \\
2 Lucerne hay & $2.98 \pm 0.47^{\mathrm{b}}$ & 1.45 & 5.52 & $\mathrm{D} 1$ \\
3 Maize silage & $1.71 \pm 0.47^{\mathrm{b}}$ & 0.56 & 3.11 & $\mathrm{D} 2$ \\
\hline
\end{tabular}

\footnotetext{
${ }^{a, b}$ Means with a common superscript did not differ with probability $P=0.05$

${ }^{1} \mathrm{O}$ : optimal $\beta$-carotene status, D1: marginally deficient, requiring $300 \mathrm{mg} / \mathrm{day}$ supplementation, D2: deficient, requiring $500 \mathrm{mg} /$ day supplementation.
}

The plasma $\beta$-carotene concentration of pasture-based cows was higher $(P<0.05)$ than that of cows on the other two systems. Group 2 tended to differ $(P<0.10)$ in plasma $\beta$-carotene concentration from Group 3 , which presented the lowest concentration. This was expected since maize silage is a poor source of available $\beta$-carotene (Block \& Farmer, 1987) and losses of up to $56 \%$ have been reported during silage fermentation (Nozierre et al., 2006). However, fresh pasture is an excellent source of $\beta$-carotene with concentrations being reported of $228 \mathrm{mg} / \mathrm{kg}$ in fresh pasture in Canada (Pekpetey et al., 1987) and $67 \mathrm{mg} / \mathrm{kg}$ in perennial ryegrass in Denmark (Lindqvist, 2012). The plasma $\beta$-carotene concentrations in the current study agree with other published studies. Bindas et al. (1984) reported concentrations of $1.5 \mathrm{mg} / \mathrm{L}$ and 4.92 $\mathrm{mg} / \mathrm{L}$ for cows fed a diets containing $72 \%$ maize silage or pasture based. Jukola et al. (1996) measured concentrations of $2.5 \mathrm{mg} / \mathrm{L}$ in lactating cows and $3.2 \mathrm{mg} / \mathrm{L}$ in dry cows fed hay-based diets.

The plasma $\beta$-carotene content of cows in groups 2 and 3 did not differ $(P>0.05)$, but the concentrations were higher for cows in group $1(P<0.05)$ (Tables 2 and 3$)$. A possible explanation relates to differences in days in milk and mobilization of body reserves between cows on these systems. The mean DIM for cows in groups 1 and 2 were 44 days and 158 days, respectively. Thus, the group 1 cows may have been in negative balance and mobilizing body reserves. In contrast, the group 2 cows may have been in a state of positive energy balance and increasing in body condition score (NRC, 2001). Noziere et al. (2006) reported that adipose tissues have a storage function from which $\beta$-carotene could be mobilized in bovines and ovines. Furthermore, Patterson (1965) reported a linear relationship between plasma carotene and free fatty acid concentrations in parturient cows in negative energy balance. 
It appears that cows in South Africa with ad libitum access to pasture, as typified by the group 1 cows, have an optimal $\beta$-carotene status, and supplementation of synthetic $\beta$-carotene is not needed. The mean plasma $\beta$-carotene concentration of group 2 cows would be considered marginal, requiring supplementation of approximately $300 \mathrm{mg} /$ day in order to achieve an optimal $\beta$-carotene status (Schweigert \& Immig, 2007). However, only five farms implementing system 2 had mean plasma $\beta$-carotene less than $3 \mathrm{mg} / \mathrm{L}$, suggesting that not all cows managed with on hay-based systems need supplementation. Therefore, these herds should be monitored regularly to make meaningful decisions about supplementation. Six herds in group 3 had had average $\beta$-carotene concentrations of less than $1.5 \mathrm{mg} / \mathrm{L}$ and were therefore classified as being in a deficient or negative status. Cows in these herds thus require supplementation of $300-500 \mathrm{mg} / \mathrm{day}$.

De Bie et al. (2019) investigated the $\beta$-carotene and vitamin $E$ status of cows in Flemish dairy herds. They reported that at least one third of cows had a deficiency in plasma $\beta$-carotene concentration, especially cows in early lactation and those housed under zero grazing conditions and fed a large proportion of silage. This supports the current data in which $27 \%$ of the cows ( 8 of 30 herds) had mean blood plasma $\beta$-carotene concentrations of less than $1.5 \mathrm{mg} / \mathrm{L}$, indicating a deficiency. Similar to the current experience, they supported the use of iCheck to assess the $\beta$-carotene status of lactating cows. More attention should be given to the $\beta$-carotene status and indirectly to the antioxidant status of dairy cows to assist in improving the health and fertility of modern high-producing cows managed under rapidly changing conditions.

A number of factors in research trials confound the interpretation of results and the initial $\beta$-carotene status such as timing and duration of supplementation. Research results and performance data were reported on pre-partum $\beta$-carotene supplementation (Kaewlamun et al., 2011; Oliveira et al., 2015), postpartum supplementation (Rakes et al., 1985; de Ondarza et.al., 2009) and in combination (Lothammer, 1976; Bian et al., 2007) resulting in contradictory outcomes. Another concern with the role of strategic supplementation during the dry period is the potential for carry-over effects post partum. A further concern is determining when supplementation should commence post-partum based on $\beta$-carotene status. These aspects were investigated in experiment 2.

The TMR was restricted pre-partum and diluted with Eragrostis hay to prevent excessive nutrient intake. In the post-partum period only the TMR was offered ad libitum. The $\beta$-carotene content of the TMR was $9.7 \mathrm{mg} / \mathrm{kg}$ DM with lucerne and Eragrostis curvula as the roughage sources. It was surprising that in most studies on $\beta$-carotene supplementation the $\beta$-carotene concentration of the basal diet was not measured. Kaewlamun et al. (2011) reported concentrations of 4.32 and $3.72 \mathrm{mg} / \mathrm{kg}$ in dry cow and lactation diets with maize silage ranging from $50 \%$ to $38 \%$ of $\mathrm{DM}$. The roughage source explains the difference in dietary $\beta$-carotene content between this and the current studies.

There was no difference in the blood $\beta$-carotene concentration between the groups before the start of supplementation $(P>0.05)$. In the supplemented group, blood $\beta$-carotene concentration increased steadily, peaked at three weeks before calving, and then decreased until the end of supplementation at eight weeks post partum. The curve appeared to flatten from week 5 to week 8 post partum, with only a $0.2 \mathrm{mg} / \mathrm{L}$ difference in concentration. In the control group, blood $\beta$-carotene concentration remained stable for the first four weeks and then decreased rapidly until it reached a nadir at three weeks post partum, after which values increased for two weeks before flattening off, similarly to the treatment group. Significant differences between the control and treatment group were observed from four weeks pre-partum to two weeks post partum $(P<0.05)$. The $\beta$-carotene status of the supplemented group remained optimal until week 2 post partum (approximately 10 days), after which it became marginal. Some cows in this group, however, remained optimal in plasma $\beta$-carotene status until four weeks post partum, supporting Weiss (1998), who reported wide variation in $\beta$-carotene status after supplementation. The pre-partum $\beta$-carotene status in the control group was on average marginal and became deficient soon after calving. The blood $\beta$-carotene concentrations during the dry period and post-partum lactation until 8 weeks are shown in Figure 1. 


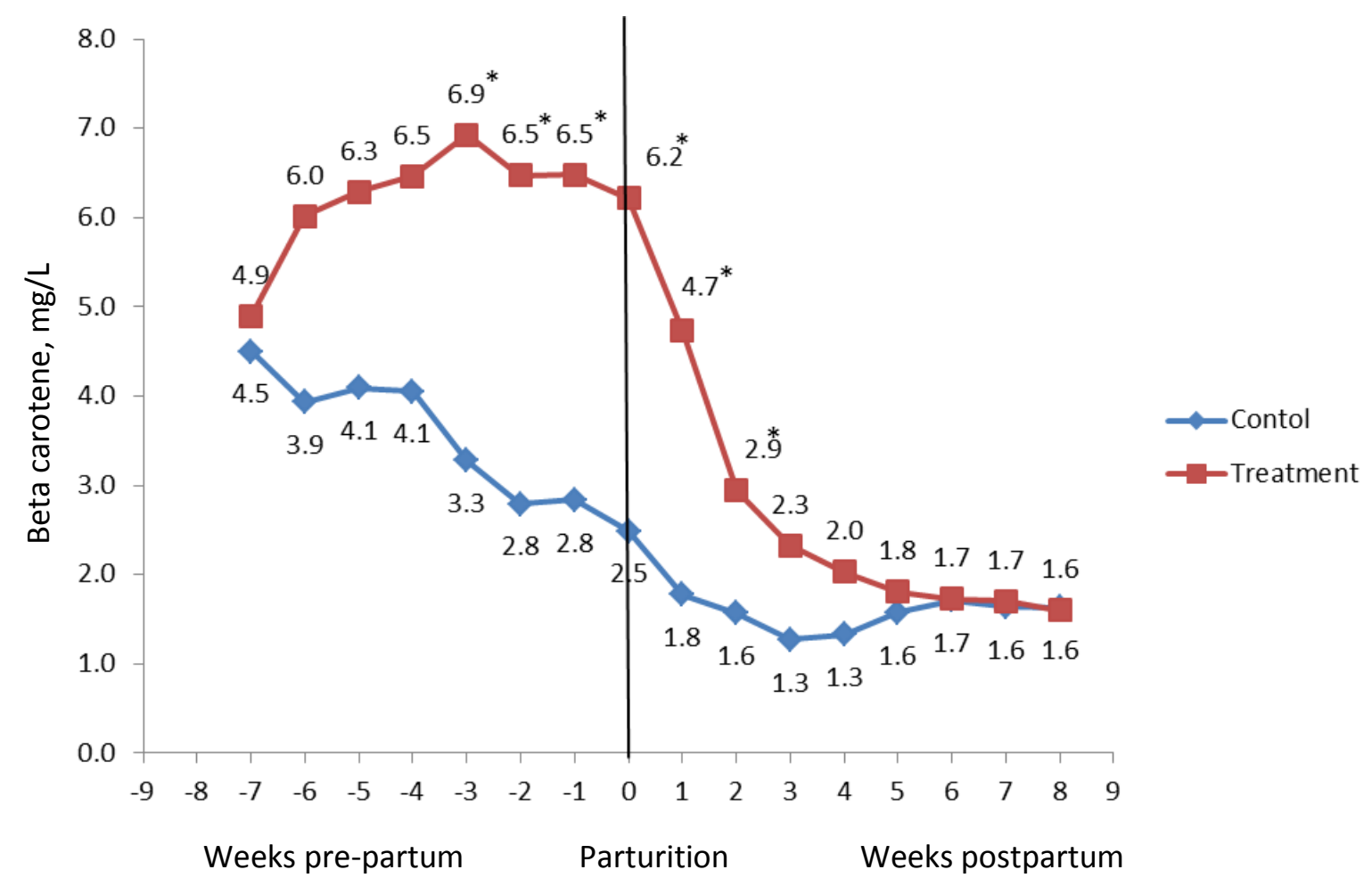

Figure 1 Blood $\beta$-carotene concentrations of Holstein cows supplemented with $1.2 \mathrm{~g} /$ day $\beta$-carotene $(n=10)$ or fed a control diet only $(n=10)$ from eight weeks pre-partum until calving

${ }^{*}$ Significant differences between treatments $(P<0.05)$

The results from the current study were similar to those obtained by Kaewlamun et al. (2011), in which cows were supplemented during the dry period with $1 \mathrm{~g} /$ day $\beta$-carotene until calving, for example the peak blood concentrations pre-partum (4 weeks vs 3 weeks) $(6.9$ vs $7.2 \mathrm{mg} / \mathrm{L}$ ) and blood $\beta$-carotene concentration at calving $(6.2$ vs $5.8 \mathrm{~g} / \mathrm{L})$. For the control, the blood $\beta$-carotene concentration at calving $(2.5 \mathrm{vs} 2.0 \mathrm{mg} / \mathrm{L})$ and the time of reaching nadir blood concentration postpartum ( 3 weeks vs 2 weeks) were similar. Overall, in the current study, differences in blood $\beta$-carotene concentrations between the supplemented group and control were from four weeks pre-partum until two weeks postpartum $(P<0.05)$ and from six weeks prepartum until two weeks postpartum $(P<0.01)$ (Kaewlamun et al., 2011). The current study confirms the results from Oliveira et al. (2015) and those of Kaewlamun et al. (2011) in that there was a minor carry-over from pre-partum $\beta$-carotene supplementation to the post-partum phase. Supplementation increased the $\beta$ carotene status of cows at calving but within two weeks this status became marginal, and supplementation should have been considered. From experiment 1 , it appears that the types of roughage and their $\beta$-carotene concentration remain the primary determinants for supplementation, and the current results suggest that continuous supplementation should be recommended until pregnancy is confirmed.

Although minor and probably biologically insignificant, carry-over effects could be attributed to storage of $\beta$-carotene in the cow's body. A number of sites have been suggested as storage organs. These include the corpus luteum (CL) (Hurley \& Doane, 1989), liver (Yang et al., 1992), and adipose tissues (Bauernfeind, 1972; Yang et al., 1992; Strachan, 1993; Mora et al., 2000). However, Underwood (1984) posited that the liver was not a significant storage site for $\beta$-carotene, as is the case for retinol. Nozière et al. (2006) reported that adipose tissue is a major storage site of $\beta$-carotene in cows during medium-term depletion. Knight et al. (2001) showed that subcutaneous fat was a storage site for $\beta$-carotene, as seen in the yellow colour of fat in pasture-fed animals. Röhrle et al. (2011) stated that the colour of adipose tissue relative to the $\beta$-carotene content could be used to differentiate between animals fed on concentrate-based and pasture-based systems. Simonne et al. (1996) found higher levels of $\beta$-carotene in subcutaneous adipose tissue in pasturefed animals than in concentrate-fed animals. Semb (1934) proposed that the bloodstream might act as a major storage reserve for $\beta$-carotene, as did Yang et al. (1992). Hurley and Doane (1989) suggested that the $\beta$-carotene stored in the corpus luteum may be used for $C L$ function during insufficient availability from the blood. However, Friesecke (1978) questioned the ability of body fat to store $\beta$-carotene owing to the short 
lifespan of fat cells. Knight et al. (2001) stated that there was no evidence to prove that $\beta$-carotene was mobilized or expelled from body fat reserves. More research is needed.

Effects of $\beta$-carotene status on reproduction parameters were not investigated in this study. However, there have been numerous reports that low levels of circulating $\beta$-carotene are associated with delayed ovulation, prolonged and low intensity in signs of oestrus, low progesterone concentration and low conception rates (Hemken \& Doanne, 1982; Rakes et al., 1985; Afrikan \& Rodway, 2000). These finding further support the current recommendation for continuous supplementation in conditions of marginal or deficient $\beta$-carotene status in dairy cows.

\section{Conclusions}

The major factors that contribute to the $\beta$-carotene status of lactating Holstein cows are the type of roughage and its $\beta$-carotene content. In general, cows on a primarily pasture-base systems maintained an optimal $\beta$-carotene status (mean $5.54 \mathrm{mg} / \mathrm{L}$ ); cows on primarily hay-based TMRs were marginally deficient (mean $2.98 \mathrm{mg} / \mathrm{L}$ ); and cows on primarily maize-based TMRs were deficient in blood $\beta$-carotene concentration (mean $1.71 \mathrm{mg} / \mathrm{L}$ ). $\beta$-carotene supplementation during the pre-partum phase resulted in optimal status until calving, with a minor carry-over effect to maintain an optimal status only for a further 10 days post partum after which cows became marginally deficient again, warranting supplementation. Further research is needed on the ability of cows to store $\beta$-carotene and its potential mobilization to assist strategic $\beta$-carotene supplementation.

\section{Acknowledgements}

The authors wish to thank DSM Nutritional Products for financial assistance and provision of the (iCheck ${ }^{\mathrm{TM}}$ ) spectrophotometer. They also thank Dr Riaan Putter for assistance with blood sampling.

\section{Authors' Contributions}

LJE and GM worked on the study design, execution and data collection. LJE, RJC and CJLDT worked on the original report, data analysis, critical review for intellectual content and approval of the version for publication.

\section{Conflict of Interest Declaration}

There is no conflict of interest associated with this manuscript

\section{References}

AOAC, 2000. Official methods of analysis. AOAC, Arlington, Washington DC.

Arkordor, F.Y. Stone J.B., Walton, J.S., Leslie, K. E. \& Buchanan-Smith, J.G., 1986. Reproductive performance of lactating Holstein cows fed supplemental $\beta$-carotene. J. Dairy Sci. 69, 2173-2178. DOI: 10.3168/jds.S00220302(86)80650-6

Arikan, S. \& Rodway, R.G., 2000. Effects of high density lipoprotein containing high or low $\beta$-carotene concentrations on progesterone production and $\beta$-carotene uptake and depletion by bovine luteal cells. Anim. Repro. Sci. 62, 253263. DOI: $10.1016 / \mathrm{s} 0378-4320(00) 00122-6$

Ballet, N., Robert, J. \& Williams, P., 2000. 19 vitamins in forages. Forage evaluation in ruminant nutrition. Pp. 399-431. https://www.cabi.org/cabebooks/ebook/20001414407

Bauernfeind, J.C., 1972. Carotenoid vitamin A precursors and analogs in foods and feeds. J. Agric. Food Chem. 20(3), 456-473. DOI: $10.1021 / \mathrm{jf} 60181 \mathrm{a} 003$

Berry, D.P., Wall, E., \& Price, J.E., 2014. Genetics and genomics of reproductive performance in dairy and beef cattle. Animal 8 (Suppl. 1), 105-121. DOI: 10.1017/S1751731114000743

Bian, S.B., Elliott, R., Immig, I. \& Sun, D.F., 2007. The influence of $\beta$-carotene supplementation on post-partum disease and subsequent reproductive performance of dairy cows in China. J. Anim. Feed Sci. 16, 370-375. https://doi.org/10.22358/jafs/74563/2007

Bindas, E.M., Gwazdauskas, F.C., Aiello, R.J., Herbein, J.H., McGilliard, M.L. \& Polan, C.E., 1984. Reproductive and metabolic characteristics of dairy cattle supplemented with B-carotene. J. Dairy Sci. 67, 1249-1255. DOI: 10.3168/jds.S0022-0302(84)81431-9

Block, E. \& Farmer, B., 1987. The status of beta-carotene and vitamin A in Quebec dairy herds: Factors affecting their status in cows and their effects on reproductive performance. Can. J. Anim. Sci. 67, 775-788. DOI: 10.4141/CJAS87-080

Butler, W.R., 2000. Nutritional interactions with reproductive performance in dairy cows. Anim. Repro. Sci., 60-61, 449451. DOI: $10.1016 / \mathrm{s} 0378-4320(00) 00076-2$

De Bie, J., Proost, K., Van Loo, H., Callens, J., Bols, P.E.J., Fransen, E. \& Leroy, M.R., 2019. B-carotene and vitamin E in the dairy industry: Blood levels and influencing factors - case study in Flanders. Vlaams Diergeneeskundig Tijdschrift 88, 137-149. DOI: 10.21825/vdt.v88i3.16018

De Ondarza, M.B., Wilson, J.W. \& Engstrom, M., 2009. Case study: Effect of supplementary $\beta$-carotene on yield of milk and milk components and reproduction in dairy cows. Prof. Anim. Sci. 25, 510-516. DOI:10.15232/S10807446(15)30742-7 
Engels, E.A.N. \& Van der Merwe, F.J. 1967. Application of an in vitro technique to South African forages with special reference to affect certain factors on the results. S. Afr. J. Anim. Sci. 10, 983-995.

Friesecke, H., 1978. The significance of $\beta$-carotene in ruminant nutrition: Field results - Europe. Roche Symposium, October, London.

Giron, H.C., 1973. Atomic absorption newsletter 12, 28. Perkin Elmer atomic spectrophotometer. https://www.scirp.org/(S(i43dyn45teexjx455qlt3d2q))/reference/ReferencesPapers.aspx?ReferencelD=1745748

Goering, H.K. \& Van Soest, P.J., 1970. Forage fibre analysis (apparatus, reagents, procedures and some applications). USDA Agricultural Handbook No. 379. https://www.scirp.org/(S(czeh2tfqyw2orz553k1w0r45))/reference/ReferencesPapers.aspx?ReferencelD=1878643

Hemken, R.W. \& Bremel, D.H., 1982. Possible role of beta-carotene in improving fertility in dairy cattle. J. Dairy Sci. 65, 1069-1073. DOI: 10.3168/jds.S0022-0302(82)82314-X

Hurley, W.L. \& Doanne, R.M., 1989. Recent developments in the role of vitamins and minerals in reproduction. J. Dairy Sci. 72, 784-804. DOI: 10.3168/jds.S0022-0302(89)79170-0

Islam, K.M.S. \& Schweigert, F.J., 2015. Comparison of three spectrophotometric methods for analysis of egg yolk carotenoids. Food Chemistry 172, 233-237. DOI: 10.1016/j.foodchem.2014.09.045

Jukola, E., Hakkarainen, J., Saloniemi, H. \& Sankari, S., 1996. Blood selenium, vitamin E, vitamin A and $\beta$-carotene concentrations and udder health, fertility treatments and fertility. J. Dairy Sci. 79, 838-845. DOI: 10.3168/jds.S0022-0302(96)76432-9

Kaewlamun, W., Okouyi, M., Humblot, P., Techakumpu, M. \& Ponter, A.A., 2011. Does supplementing dairy cows with $\beta$ carotene during the dry period affect postpartum ovarian activity, progesterone, and cervical and uterine involution? Theriogenology 75, 1029-1038. DOI: 10.1016/j.theriogenology.2010.11.010

Kirchgessner, M., Friesecke, H. \& Koch, G., 1967. Nutrition and the composition of milk. Crosby, Lockwood \& Son, Ltd., London, U.K.

Knight, T.W., Death, A.F., Lambert, M.G. \& McDougall, D.B., 2001. The rate of reduction in carotenoid concentration in fat of steers fed a low carotenoid ration, and the role of increasing carcass fatness. Aust. J. Agric. Res. 52, 10231032. https://doi.org/10.1071/AR01017

Kumar, S., Pandey, A.K., Mutha Rao, M. \& Razzaque, W.A.A., 2010. Role of $\beta$-carotene / vitamin A in animal reproduction. Vet. World 3, 236-237.

Lindqvist, H., 2012. Alphatocopherol and $\beta$-carotene in forages and their utilisation by dairy cows in organic production. Doctoral thesis, Swedish University of Agricultural Sciences, Skara.

Livingston, A.L., Knowles, R.E. \& Kohler, G.O., 1970. Xantophyl, carotene and alpha tocopherol stability in alfalfa as affected by pilot and industrial scale dehydration. USDA Agric. Res. Serv. Techn. Bull. 1414.

Lothammer, K.H., Schams, D. \& Scholz, H., 1978. Untersuchhungen uber eine spezifische Vitamin A - unabhangige wirking des $\beta$-carotins auf die fruchtbarkeit von laktierented kunhen. Zuchthygiene 13, 76-82.

Lothammer, K.H., 1979. Importance of $\beta$-carotene for the fertility of dairy cattle. Feedstuffs 51, 37-38.

Machpesh, G., 2014. An investigation of the $\beta$-carotene status of Holstein cows in South Africa. MSc dissertation, University of Pretoria, Pretoria, South Africa.

Marino, V.M., Schadt,I., Carpino, S., Cuccamo, M., La Terra,S., Guardiano, C. \& Licitra, G., 2014. Effect of Sicilian pasture feeding management on content of alphatocopherol and $\beta$-carotene content in cow milk. J. Dairy Sci. 97, 543-551. DOI: 10.3168/jds.2013-7005

McDowell, L.R., 2000. Vitamins in animal and human nutrition. Second ed. lowa State Univ. Press, Ames. pp 46-47.

Mogenson, L., Troels, K., Soegaard, K., Jensen, S.K. \& Sehested, J., 2012. Alpha-tocopherol and $\beta$-carotene in roughages and milk in organic herds. Livest. Sci. 145, 44-54. DOI: 10.1016/J.LIVSCI.2011.12.021

Mora, O., Romano, J.L., González, E., Ruiz, F.J. \& Shimada, A., 2000. Low cleavage activity of 15,15'-dioxygenase convert $\beta$-carotene to retinol in cattle compared with goats, is associated with the yellow pigmentation of adipose tissue. Int. J. Vitam. Nutr. Res. 70, 199-205. DOI: 10.1024/0300-9831.70.5.199

Nozière, P., Graulet, B., Lucas, A., Martin, B., Grolier, P. \& Doreau, M., 2006. Carotenoids for ruminants: from forages to dairy products. Anim. Feed Sci. Technol. 131, 418-450. DOI: 10.1016/J.ANIFEEDSCI.2006.06.018

NRC, 2001. nutrient requirements of dairy cattle. Seventh edition. National Academic Press, Washington DC, USA.

Oliveira, R.C., Guerreiro, B.M., Morais Junior, N.N., Araujo, R.L., Pereira, R.A.N. \& Pereira, M.N., 2015. Supplementation of prepartum dairy cows with $\beta$-carotene. J. Dairy Sci. 98, 6304-6314. DOI: 10.3168/jds.2014-9037

Park, Y.M., Anderson, M.J., Walters, J.L. \& Mahoney, A.W., 1983. Effect of processing method and agronomic variables on carotene content in forages and predicting carotene in alfalfa hay with NIRS. J. Dairy Sci. 66, 235-245. DOI: 10.3168/JDS.S0022-0302(83)81782-2

Patterson, D.S.P., 1965. Plasma carotenoids and fat mobilization in stall-fed cattle. Nature $206,1069$. https://doi.org/10.1038/2061069a0

Pekpetey, F.R., Palmer, W.M. \& Ingalls, J.R., 1987. Seasonal variation in serum $\beta$-carotene and vitamin A and their association with postpartum reproductive performance of Holstein cows. Can J. Anim Sci. 67, 491-450. DOI: 10.4141/CJAS87-047

Rakes, A.H., Owens, M.P., Britt, J.H. \& Whitlow, L.W., 1985. Effects of adding $\beta$-carotene to rations of lactating cows consuming different forages. J. Dairy Sci. 68, 1732-737. DOI: 10.3168/jds.S0022-0302(85)81019-5

Ralston, A.T. \& Dyer I.A., 1959. Relationship of liver and plasma carotenoid and vitamin A content in cattle by location and season. J. Anim. Sci. 18, 874-879. DOI: 10.2527/JAS1959.183874X

Roche, J.R., Burke, C.R., Meier, S. \& Walker, C.G., 2011. Nutrition reproduction interaction in pasture-based systems: Is nutrition a factor in reproduction failure? Anim. Prod. Sci. 51, 40-52. DOI: 10.1071/AN10162 
Robinson, P.H, Givens, D.I. \& Getachew, G., 2004. Evaluation of NRC, UC Davis and ADAS approaches to estimate the metabolizable energy values of feeds at maintenance energy intake from equations utilizing chemical assays and in vitro determinations. Anim. Feed Sci. Technol. 114, 75-90. DOI: 10.1016/J.ANIFEEDSCI.2003.12.002

Röhrle, F.T., Moloney, A.P., Osorio, M.T., Luciano, G., Priolo, A., Caplan, P. \& Monahan F.J. 2011. Carotenoid, colour and reflectance measurements in bovine adipose tissue to differentiate between beef from different feeding systems. Meat Sci. 88, 347-353. DOI: 10.1016/j.meatsci.2011.01.005

Samuels, M.L., 1989. Statistics for the life sciences. Collier MacMillan, London

Schierle, J., Härdie, W., Faccin, N., Bühler, I. \& Schüep, W., 1995. Example 8: Geometrical isomers of $\beta$-carotene. A rapid routine method for quantitative determination. In: G. Britton, S. Liaaen-Jensen \& H. Pfander. Carotenoids. Volume 1A: Isolation and analysis. Birkhäuser Verlag, Basel. Pp 265-272.

Schweigert, F.J. \& Immig, I., 2007. Rapid assessment of $\beta$-carotene status. International Dairy Topics 6, 15-17.

Semb, J., Baumann, C.A. \& Steenbock, H., 1934. Fat-soluble vitamins. 41. The carotene and vitamin a content of colostrum. J. Biol. Chem. 107, 697-703.

Simonne, A.H., Green, N.R. \& Bransby, J.I., 1996. Consumer acceptability and $\beta$-carotene content of beef as related to cattle finishing diets. J. Food Sci. 61, 1254-1256. DOI: 10.1111/J.1365-2621.1996.TB10973.X

Strachan, D.B., Yang, A. \& Dillon, R.D.,1993. Effect of grain feeding on fat colour and other carcass characteristics in previously grass-fed Bos indicus steers. Aust. J. Exp. Agric. 33, 269-273. DOI: 10.1071/EA9930269

Tilley, J.M.A. \& Terry, R.A., 1963. A two-stage technique for the in vitro digestion of forage crops. J. Brit. Grasslands Soc. 18, 104-111. DOI: 10.1111/J.1365-2494.1963.TB00335.X

Underwood, B.A., 1984. Vitamin A in animal and human nutrition. In: M.B. Sporn, A.B. Roberts \& D.S. Goodman (ed). The retinoids. Vol. 1. Academic Press, New York, NY. Pp 281-392

Weiss, W.P., 1998. Requirements of fat-soluble vitamins for dairy cows: A review. J. Dairy Sci. 81, 2493-2501. DOI: 10.3168/jds.S0022-0302(98)70141-9

Wilkinson, J.M. \& Rinne, M., 2018. Highlights of progress in silage conservation and future perspectives. Grass Forage Sci. 73, 40-52. DOI: 10.1111/GFS.12327

Yang, A., Larsen, T.W. \& Fume, R.K. 1992. Carotenoid and retinol concentrations in serum, adipose tissue and liver and carotenoid transport in sheep, goats and cattle. Aust. J. Agric. Res. 43, 1809-1817. DOI: 10.1071/AR9921809 